\title{
Originals
}

\section{Enhanced hepatic insulin sensitivity, but peripheral insulin resistance in patients with Type 1 (insulin-dependent) diabetes}

\author{
O. Hother-Nielsen ${ }^{1}$, O.Schmitz ${ }^{2}$, J. Bak ${ }^{1}$ and H. Beck-Nielsen ${ }^{1}$ \\ ${ }^{1}$ Division of Endocrinology and Metabolism, Departments of Medicine and Clinical Chemistry, Aarhus Amtssygehus and \\ ${ }^{2}$ Medical Department C, Aarhus Kommunehospital, Aarhus, Denmark
}

\begin{abstract}
Summary. Sensitivity to insulin in vivo was studied in 8 normal weight C-peptide negative Type 1 (insulin-dependent) diabetic patients (age $23 \pm 1$ years, diabetes duration $6 \pm$ 2 years), and in 8 age, weight and sex matched healthy subjects, using the euglycaemic clamp and $3 \cdot{ }^{3} \mathrm{H}$-glucose tracer technique. Prior to the study diabetic patients were maintained normoglycaemic overnight by a glucose controlled insulin infusion. Sequential infusions of insulin in 3 periods of $2 \mathrm{~h}$ resulted in mean steady state insulin levels of $12 \pm 2$ versus $11 \pm 1,18 \pm 2$ versus $18 \pm 2$ and $28 \pm 3$ versus $24 \pm$ $2 \mu \mathrm{U} / \mathrm{ml}$ in diabetic patients and control subjects. Corresponding glucose utilization rates were $2.4 \pm 0.2$ versus $2.4 \pm$ $0.1,2.4 \pm 0.2$ versus $3.0 \pm 0.3$ and $2.9 \pm 0.3$ versus $4.6 \pm$ $0.6 \mathrm{mg} \cdot \mathrm{kg}^{-1} \cdot \mathrm{min}^{-1}, p<0.02$. Portal insulin values in the three periods were calculated to $12 \pm 2$ versus $25 \pm 3,18 \pm 2$ versus $32 \pm 3$ and $28 \pm 3$ versus $37 \pm 3 \mu \mathrm{U} / \mathrm{ml}$ in the diabetic patients and control subjects using peripheral insulin and C-peptide concentrations and assuming a portal to peripher-
\end{abstract}

al insulin concentration gradient of 1 in diabetic patients and of 2.4 in control subjects. Corresponding glucose production rates were $2.5 \pm 0.2$ versus $2.4 \pm 0.1,1.6 \pm 0.1$ versus $0.9 \pm 0.2$ and $0.7 \pm 0.1$ versus $0.4 \pm 0.2 \mathrm{mg} \cdot \mathrm{kg}^{-1} \cdot \mathrm{min}^{-1}$. Using this approach the insulin dose-response curve for the peripheral glucose utilization was right-ward shifted, while the dose-response curve for the hepatic glucose production as a function of portal insulin levels was left-ward shifted. We conclude that in vivo insulin action is increased in the liver but decreased in peripheral tissues in insulin treated Type 1 diabetic patients. Presumably these oppositely directed changes in insulin action are acquired defects, secondary to the present mode of peripheral insulin treatment.

Key words: Type 1 (insulin-dependent) diabetes, insulin sensitivity, insulin resistance, glucose utilization, hepatic glucose production.
Studies of in vivo insulin action in conventionally treated Type 1 (insulin-dependent) diabetic patients have shown peripheral insulin resistance [1-9]. The hepatic glucose production has been found to be increased in the basal fasting state, but normally, i.e. totally suppressed at high insulin concentrations of $100 \mu \mathrm{U} / \mathrm{ml}[1-5,10]$. Hence, from these studies it was not possible to conclude whether the liver of Type 1 diabetic patients had normal sensitivity to insulin. The interpretation was further confounded by the fact that the basal fasting plasma glucose concentrations in these studies were different in normal subjects and diabetic patients, and that the insulin treatment of the diabetic patients was usually stopped for $12-24 \mathrm{~h}$ before the studies. This procedure might have induced some degree of metabolic derangement and thereby influenced the measurement of insulin sensitivity.

Furthermore, in all previous human studies hepatic insulin sensitivity has been evaluated as a function of peripheral insulin levels, although it is well document- ed that the insulin concentration in the portal vein is normally several times higher than in peripheral arteries in non-diabetic subjects [11-20].

Since hepatic overproduction of glucose in diabetes is regarded as the most important factor responsible for fasting hyperglycaemia, abnormalities in hepatic insulin sensitivity may be of clinical importance.

Therefore, the aim of the present study was to evaluate the hepatic insulin sensitivity in Type 1 diabetic patients at insulin concentrations normally encountered in such patients during conventional insulin treatment. To do this we have chosen a new approach: Plasma glucose concentration in the diabetic patients was normalised and kept normal overnight before the study using a glucose controlled insulin infusion system. Insulin action on glucose utilization and on hepatic glucose production was then measured at low physiologic insulin concentrations using the euglycaemic clamp and $3-{ }^{3} \mathrm{H}$-glucose tracer technique. Furthermore, hepatic insulin action was evaluated as a func- 
Table 1. Clinical and laboratory characteristics of Type 1 (insulin dependent) diabetic patients and control subjects

\begin{tabular}{|c|c|c|c|c|c|c|c|c|}
\hline & $\begin{array}{l}\text { Age } \\
\text { (years) }\end{array}$ & $\begin{array}{l}\text { BMI } \\
\left(\mathrm{kg} / \mathrm{m}^{2}\right)\end{array}$ & $\begin{array}{l}\text { Fasting } \\
\text { plasma } \\
\text { glucose } \\
(\mathrm{mmol} / \mathrm{l})\end{array}$ & $\begin{array}{l}\text { Fasting } \\
\text { plasma } \\
\text { insulin } \\
(\mu \mathrm{U} / \mathrm{ml})\end{array}$ & $\begin{array}{l}\text { Diabetes } \\
\text { duration } \\
\text { (years) }\end{array}$ & $\begin{array}{l}\text { Insulin } \\
\text { dose } \\
\text { (U/day) }\end{array}$ & $\begin{array}{l}\text { Insulin } \\
\text { binding } \\
\text { capacity } \\
\text { of IgG } \\
(\mathrm{mU} / \mathrm{ml})\end{array}$ & $\begin{array}{l}\text { Fructos- } \\
\text { amine } \\
(\mathrm{mmol} / \mathrm{l})\end{array}$ \\
\hline \multicolumn{9}{|c|}{ Diabetic patients } \\
\hline 1 & 21 & 23.7 & 5.4 & 11 & 16 & 64 & 0.01 & 4.0 \\
\hline 2 & 31 & 20.9 & 6.6 & 21 & 3 & 45 & 1.09 & 3.5 \\
\hline 3 & 28 & 22.0 & 5.5 & 11 & 3 & 52 & 0.28 & 3.2 \\
\hline 4 & 19 & 18.9 & 5.1 & 9 & 4 & 56 & 0.02 & 4.4 \\
\hline 5 & 23 & 21.5 & 5.5 & 9 & 5 & 30 & 0.01 & 4.3 \\
\hline 6 & 19 & 23.1 & 4.7 & 16 & 3 & 24 & 0.13 & 5.7 \\
\hline 7 & 19 & 20.1 & 4.3 & 8 & 6 & 34 & 0.04 & 3.8 \\
\hline 8 & 18 & 19.6 & 5.3 & 13 & 11 & 54 & 0.17 & 4.2 \\
\hline mean \pm & 22.3 & 21.2 & 5.3 & 12 & 6.4 & 45 & 0.22 & 4.1 \\
\hline SD & 1.7 & 0.6 & 0.2 & 2 & 1.7 & 5 & 0.13 & 0.3 \\
\hline \multicolumn{9}{|c|}{ Control subjects } \\
\hline mean \pm & 23.9 & 22,6 & 5.2 & 10 & & & & 2.2 \\
\hline SD & 0.7 & 0.2 & 0.1 & 1 & & & & 0.2 \\
\hline
\end{tabular}

Fasting plasma glucose and insulin in the diabetic patients denotes values measured after maintenance of normoglycaemia overnight by use of a Biostator

tion of portal insulin levels estimated from peripheral plasma insulin and C-peptide measurements.

\section{Subjects and methods}

\section{Subjects}

Eight male Type 1 diabetic patients participated in the study. Clinical and laboratory data are given in Table 1 . None had evidence of renal or hepatic disease on routine laboratory examination, and none was anaemic. All patients had been treated with highly purified porcine insulin preparations since the onset of their diabetes. Insulin was administered in one or two daily injections, employing rapid and/or intermediate acting insulin preparations. All were without residual endogenous insulin secretion, i.e. plasma C-peptide concentration below $0.06 \mathrm{nmol} / 16 \mathrm{~min}$ after intravenous administration of $1 \mathrm{mg}$ glucagon (NOVO, Bagsvaerd, Denmark).

Eight healthy male subjects were studied as a normal control group. None had a family history of diabetes mellitus.

All subjects were consuming a weight-maintaining diet containing at least $200 \mathrm{~g}$ of carbohydrate per day. None of the diabetic patients or control subjects were taking any medication other than insulin at the time of the study. The diabetic patients received their last subcutaneous injection of insulin $24 \mathrm{~h}$ before the clamp study to allow for the clearance of subcutaneous depots of insulin that could interfere with the test.

All studies were started in the morning following a $10 \mathrm{~h}$ overnight fast. In all experiments, subjects were placed in bed and maintained supine thereafter. The purpose, nature and potential risks of the study were carefully explained to all subjects before consent to participate was obtained. The protocol of the study was reviewed and approved by the regional ethical committee of the county of Aarhus.

\section{Insulin clamp study}

The diabetic patients were admitted on the day before the clamp study; at midnight, $8 \mathrm{~h}$ before the clamp study, they were connected to a glucose controlled insulin infusion system (Biostator GCIIS, Life Science Instruments, Miles Laboratories, Elkhart, Ind, USA). A catheter was inserted in an antecubital vein of the right arm for the administration of all test infusions, another catheter was placed in a forearm vein of the left arm for continuous blood withdrawal by the Biostator, and a third catheter was inserted in a wrist vein on the left arm for intermittent blood sampling.

To circumvent the problems encountered when comparing subjects studied at different plasma glucose levels, and for the purpose of studying glucose turnover rates at low physiologic insulin concentrations, plasma glucose concentration in the diabetic patients was normalised and kept normal during the night by the Biostator using the preprogrammed algorythm mode $3: 0$ and the following constants: $\mathrm{KR}=70, \mathrm{KF}=67, \mathrm{BI}=80, \mathrm{QI}=40$ and $\mathrm{RI}=0.2 \mathrm{mU} \cdot \mathrm{kg}^{-1}$. $\mathrm{min}^{-1}$. The glucose infusing capacity of the Biostator was not used.

Control subjects were admitted at 07.00 hours on the day of the study and were cannulated and attached to the Biostator as described above. In both diabetic patients and control subjects the left hand and forearm were maintained at $50^{\circ} \mathrm{C}$ in a heated plexiglas box to ensure arterialisation of venous blood [21]. A primed $(40 \mu \mathrm{Ci})$ continuous $(0.40 \mu \mathrm{Ci} / \mathrm{min})$ infusion of $3-{ }^{3} \mathrm{H}$-glucose was started at 08.00 hours and continued throughout the study for isotopic determination of glucose turnover.

The first $2 \mathrm{~h}$ period from 08.00 to 10.00 hours was used for tracer equilibration and determination of basal glucose turnover. During this period no insulin was infused in control subjects whereas insulin was infused at a rate of $0.25 \mathrm{mU} \cdot \mathrm{kg}^{-1} \cdot \mathrm{min}^{-1}$ in diabetic patients to compensate for the missing endogenous insulin secretion. During the next two 2-h periods insulin infusion was increased with 0.15 and $0.35 \mathrm{mU} \cdot \mathrm{kg}^{-1} \cdot \mathrm{min}^{-1}$ so that diabetic patients were infused with 0.40 and $0.60 \mathrm{mU} \cdot \mathrm{kg}^{-1} \cdot \mathrm{min}^{-1}$ and control subjects with 0.15 and $0.35 \mathrm{mU} \cdot \mathrm{kg}^{-1} \cdot \mathrm{min}^{-1}$. Concurrent with these insulin infusions variable amounts of a $20 \%$ glucose solution were infused using a volumetric precision pump (IMED 922, IMED Scandinavia, Stockholm, Sweden) to maintain the blood glucose concentration at $5.0 \mathrm{mmol} / \mathrm{l}$. The necessary adjustments in the glucose infusion rate were made empirically depending on changes in the blood glucose concentration observed during continuous glucose monitoring by the Biostator. Independent measurements of arterialised blood glucose from the wrist vein (YSI Glucose Analyzer, Yellow Springs Instrument Co., Yellow Springs, Ohio, USA) were used to recalibrate the Biostator every $30 \mathrm{~min}$ using the pump ratio adjustment knob. Intermittent blood samples were drawn from the arterialised wrist vein for determination of glucose specific activity, insulin and C-peptide.

All test solutions were prepared on the day of the study, Porcine insulin (Velosulin, Nordisk Insulin, Gentofte, Denmark) $160 \mathrm{U}$ in 
$500 \mathrm{ml} 0.9 \%$ saline. Tubings were flushed with $100 \mathrm{ml}$ and pre-run $(1 \mathrm{ml} / \mathrm{min})$ for $2 \mathrm{~h}$ before insulin infusion was started. D-3- ${ }^{3} \mathrm{H}$-glucose (New England Nuchlear, Boston, Mass, USA) was diluted in appropriate volumes of $0.9 \%$ saline.

\section{Analytical determinations}

Plasma for glucose and $3-{ }^{3} \mathrm{H}$-glucose activity measurements was colleeted in fluoride containing polypropylene tubes. Glucose in plasma was analysed using a glucose dehydrogenase method (Merck enzymatic kit). For tritiated glucose activity $500 \mu \mathrm{l}$ of plasma was deproteinized with $1 \mathrm{ml} \mathrm{Ba}\left(\mathrm{OH}_{2}\right)_{2} 0.3 \mathrm{~N}$ and $1 \mathrm{ml} \mathrm{ZnSO}, 0.3 \mathrm{~N}$ (Sigma, St. Louis, Mo, USA), $500 \mu l$ of the supernatant was evaporated to dryness at $70^{\circ} \mathrm{C}$ under vacuum to eliminate tritium labelled water, resuspended in $500 \mu \mathrm{l}$ distilled water, mixed with $5 \mathrm{ml}$ Aqualuma plus (Lumac, Schaesberg, The Netherlands) and counted in a liquid scintillation counter. Ten $\mu$ of the infusate was added to $500 \mu$ of the subjects baseline plasma and run through the same procedure together with the plasma samples and a blank baseline plasma sample serving for background determination. Both plasma, infusate and background determinations were run in duplicate and in the same assay for a given subject.

Plasma insulin and plasma C-peptide concentrations were measured with radioimmunological methods [22, 23]; in both diabetic patients and control subjects plasma was incubated $2 \mathrm{~h}$ at $37^{\circ} \mathrm{C}$ and treated with polyethylene glucol before estimation of free insulin concentration [24]. Insulin antibodies and fructosamine were measured as previously described $[25,26]$.

\section{Calculations}

The amount of glucose infused to maintain euglycaemia was calculated at $10 \mathrm{~min}$ intervals throughout the experiments. Because equilibration between plasma insulin concentrations and insulin concentrations in the extravascular compartments is slow and takes at least $90 \mathrm{~min}$ [27], only the glucose infusion rates over the final $30 \mathrm{~min}$ of each insulin infusion period were used for the assessment of insulin action. Under these steady state conditions the amount of glucose infused to maintain euglycaemia equals the sum of the insulin induced increase in glucose utilization and the insulin induced suppression of hepatic glucose production. Rates of total glucose appearance and utilization during the insulin infusion periods were calculated according to Steele's non steady-state equations [28] using a value of 0.65 for the pool fraction [29]. Hepatic glucose production rate was calculated by subtracting exogenous glucose infusion rate from the rate of total glucose appearance calculated by the tracer technique.

Portal insulin concentrations at steady state were estimated using the equation

$\mathrm{PI}_{\mathrm{t}}=\mathrm{AI} \mathrm{I}_{\mathrm{t}}+\left(\mathrm{PI}_{\mathrm{o}}-\mathrm{AI}_{\mathrm{o}}\right) \frac{\mathrm{CP}}{\mathrm{CP}_{\mathrm{o}}}$

where PI and AI are the portal and the arterial plasma insulin concentrations, respectively, $\mathrm{CP}$ is the arterial plasma $\mathrm{C}$-peptide concentration and the subscripts $t$ and o indicate time and fasting state, respectively. In control subjects fasting portal venous insulin concentrations were estimated with a value of 2.4 for the portal venous-systemic insulin gradient. This value is based on the result of seven studies comprising 61 subjects in which this gradient averaged $2.42 \pm 0.06$ [30]. A value of 1 was used in diabetic patients since they had no evidence of endogenous insulin secretion.

\section{Statistical analysis}

All data are presented as mean \pm SEM. Statistical comparisons between and within groups were performed using the unpaired Student's t-test, and differences with $p$ values less than 0.05 were considered significant.
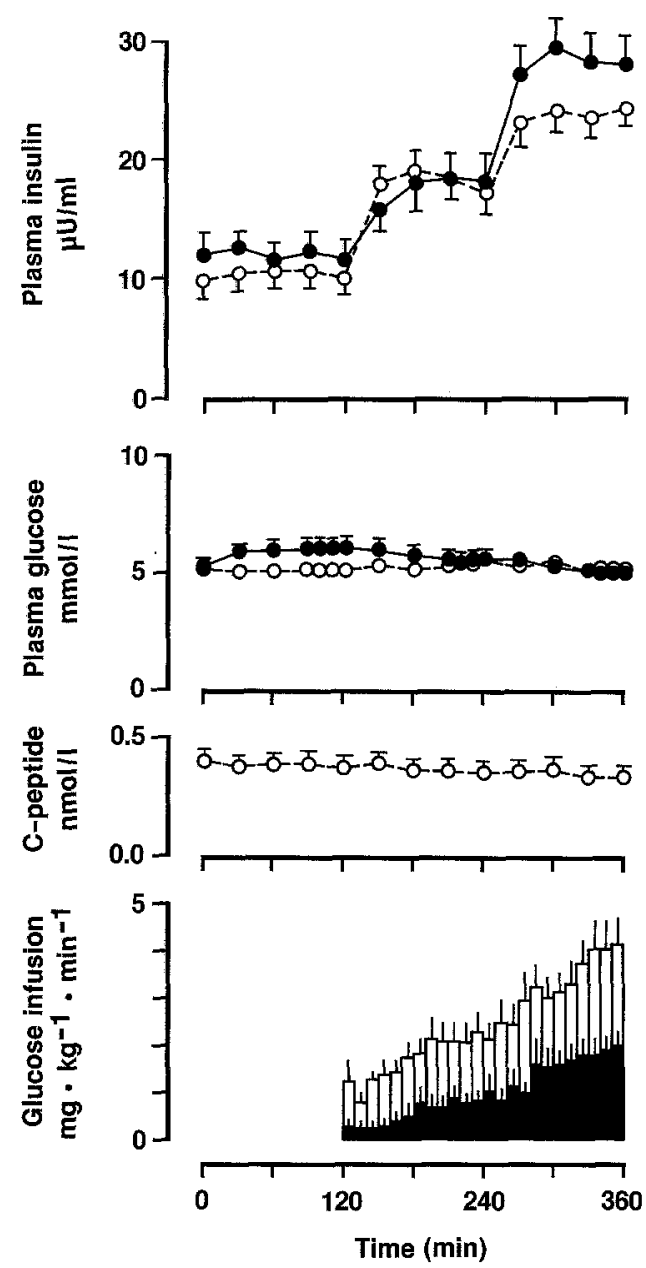

Fig. 1. Plasma glucose, insulin and C-peptide concentrations and glucose infusion rates during the clamp study in diabetic patients $(\longrightarrow$ and $\square)$ and control subjects $(\mathrm{O}-\mathrm{O}$ and $\square)$

\section{Results}

\section{Fasting plasma glucose and insulin concentrations before the clamp study}

Euglycaemia in the diabetic patients was achieved by an overnight feedback glucose controlled insulin infusion resulting in normoglycaemia in $6 \mathrm{~h}$ before the study. At the start of the clamp study ( 08.00 hours) both plasma glucose concentrations $5.3 \pm 0.2$ versus $5.2 \pm 0.1 \mathrm{mmol} / 1$ (NS), and peripheral plasma free insulin concentrations $12 \pm 2$ versus $10 \pm 2 \mu \mathrm{U} / \mathrm{ml}$ (NS), were comparable in diabetic patients and control subjects.

\section{Euglycaemic clamp}

Mean plasma glucose, insulin and C-peptide concentrations during the clamp studies are shown in Figure 1.

During the first period plasma glucose concentrations increased in the diabetic patients. Thus, steady state glucose concentrations were slightly higher than 

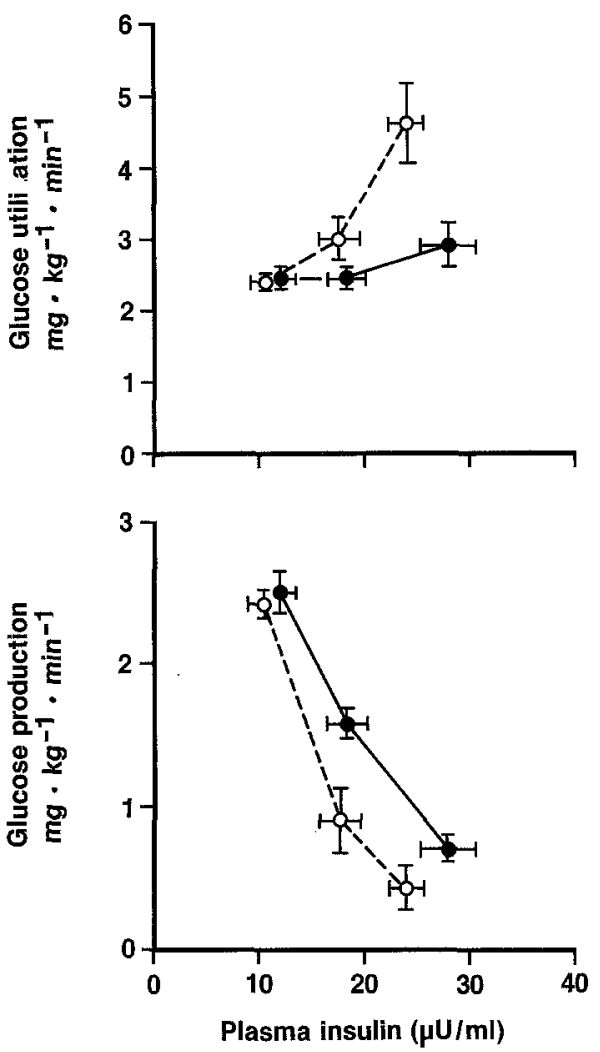

Fig. 2. Dose-response curves for the insulin action on glucose utilisation (upper panel) and glucose production (lower panel) as functions of peripheral insulin concentrations in diabetic patients $(\boldsymbol{O})$ and control subjects $(O)$

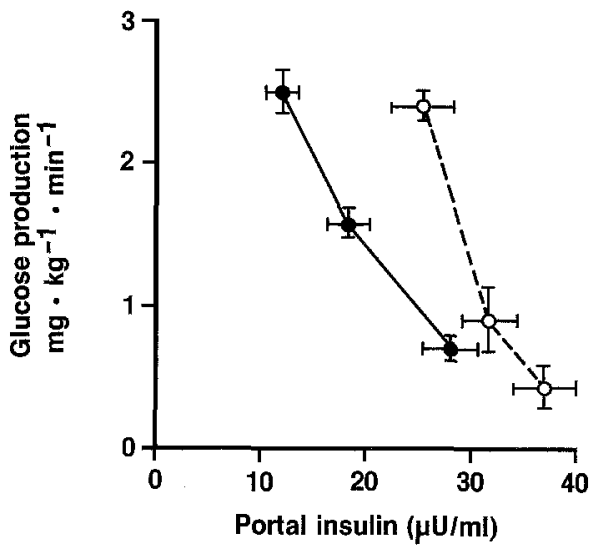

Fig.3. Hepatic glucose production as a function of the portal insulin concentrations in diabetic patients $(O)$ and control subjects $(O)$

in the control subjects $6.1 \pm 0.5$ versus $5.1 \pm 0.1 \mathrm{mmol} / 1$ $(p<0.05)$, while during the second and third period plasma glucose levels were comparable $5.5 \pm 0.3$ versus $5.3 \pm 0.1(p=\mathrm{NS})$ and $5.0 \pm 0.2$ versus $5.2 \pm 0.1 \mathrm{mmol} / 1$ $(p=\mathrm{NS})$.

In all three periods steady state plasma free insulin concentrations were comparable in diabetic patients and control subjects $12 \pm 2$ versus $11 \pm 1 \quad(p=\mathrm{NS})$, $18 \pm 2$ versus $18 \pm 2(p=\mathrm{NS})$ and $28 \pm 3$ versus $24 \pm$ $2 \mu \mathrm{U} / \mathrm{ml}(p=\mathrm{NS})$. In control subjects the mean plasma $\mathrm{C}$-peptide concentration decreased slightly from
$0.38 \pm 0.05 \mathrm{nmol} / 1$ to $0.36 \pm 0.05 \mathrm{nmol} / 1$ ( $p=\mathrm{NS}$ ) during the second and to $0.33 \pm 0.05 \mathrm{nmol} / 1(p=\mathrm{NS})$ during the third period.

\section{Glucose utilization}

Significantly less gllucose was infused in diabetic patients compared to control subjects to maintain euglycaemia. During the second period $0.76 \pm 0.24$ versus $2.22 \pm 0.43 \mathrm{mg} \cdot \mathrm{kg}^{-1} \cdot \mathrm{min}^{-1}(p<0.01)$, and during the third period $2.14 \pm 0.33$ versus $4.11 \pm 0.56 \mathrm{mg} \cdot \mathrm{kg}^{-1}$. $\min ^{-1}(p<0.01)$, (Fig. 1).

Glucose utilization rates determined by the $3-{ }^{3} \mathrm{H}-$ glucose tracer technique were normal in the diabetic patients during the first period, $2.43 \pm 0.16$ versus $2.40 \pm 0.11 \mathrm{mg} \cdot \mathrm{kg}^{-1} \cdot \mathrm{min}^{-1}(p=\mathrm{NS})$, slightly lower during the second period $2.43 \pm 0.16$ versus $3.01 \pm$ $0.27 \mathrm{mg} \cdot \mathrm{kg}^{-1} \cdot \mathrm{min}^{-1}(p=\mathrm{NS})$ and significantly lower during the third period, $2.90 \pm 0.29$ versus $4.62 \pm$ $0.55 \mathrm{mg} \cdot \mathrm{kg}^{-1} \cdot \mathrm{min}^{-1}(p<0.02)$ (Fig. 2).

\section{Glucose production}

Basal glucose production rates in diabetic patients and control subjects were found to be identical at euglycaemia, $2.53 \pm 0.16$ versus $2.40 \pm 0.10 \mathrm{mg} \cdot \mathrm{kg}^{-1} \cdot \mathrm{min}^{-1}$ $(p=$ NS). During second and third periods glucose production rates were highest in the diabetic patients, $1.59 \pm 0.10$ versus $0.90 \pm 0.23 \mathrm{mg} \cdot \mathrm{kg}^{-1} \cdot \mathrm{min}^{-1} \quad(p<$ $0.02)$ and $0.70 \pm 0.07$ versus $0.42 \pm 0.16 \mathrm{mg} \cdot \mathrm{kg}^{-1}$. $\min ^{-1}(p<0.05)$, (Fig. 2).

Portal insulin concentrations in control subjects were estimated to $25 \pm 3,32 \pm 3$ and $37 \pm 3 \mu \mathrm{U} / \mathrm{ml}$ during the three periods. Assuming that insulin levels in diabetic patients were identical in portal and peripheral plasma, the dose-response curve for hepatic glucose production as a function of portal insulin levels was found to be left-ward shifted in diabetic patients compared to control subjects (Fig.3).

\section{Discussion}

In the present study we have attempted to examine whether the in vivo insulin effect on hepatic glucose production is altered in patients with Type 1 diabetes mellitus. This issue may have important implications with respect to therapy as well as with respect to the pathogenesis of the insulin resistance.

We have employed a new approach including maintenance of normoglycaemia during the night preceding the dose-response study and evaluation of the hepatic insulin sensitivity as a function of portal insulin levels. Using this approach we found that in the diabetic patients the fasting glucose production rate was normal, the insulin stimulated change in glucose utilization was subnormal and the inhibition of the hepatic glucose production rate occurred at lower portal insulin concentrations than in normal subjects. 
Previously, insulin action on hepatic glucose production in Type 1 diabetic patients has been studied either at hyperglycaemia or at normoglycaemia and high insulin concentrations around $100 \mu \mathrm{U} / \mathrm{ml}$. At these high insulin levels hepatic glucose production was found to be totally suppressed $[1-5,10]$. This however, does not exclude that hepatic insulin sensitivity could be altered at lower insulin concentrations. Indeed the fasting glucose production rate has been found to be increased in nearly all previous studies $[1-5,9,10]$, and this finding has been suggested as indicating that the diabetic liver was insulin resistant [1]. However, in most of these studies insulin therapy was stopped $24 \mathrm{~h}$ prior to the study. This leads to hypoinsulinaemia, and probably also metabolic derangement in the hours preceding the study. The degree of hyperglycaemia may be an indicator of the severity of these changes. Since the diabetic patients in the previous studies were hyperglycaemic, it is therefore quite possible that the increased glucose production rates were due to insulin deficiency rather than to a reduced hepatic insulin sensitivity. Apart from the current study only one other study has found fasting glucose production rates to be normal in Type 1 diabetic patients [31]. In that study near normoglycaemia was obtained by insulin pump treatment (CSII); and fasting plasma insulin concentrations in both diabetic patients and normal subjects were comparable to the values in the current study. These results, therefore, support the conclusion that in Type 1 diabetic patients fasting glucose production rate is normal, provided hyperglycaemia and insulin deficiency is avoided.

Although the insulin action in the liver must depend on the insulin concentration reaching it, all previous studies have evaluated hepatic insulin action as a function of peripheral insulin concentrations. While insulin concentrations in the portal vein and in the peripheral circulation may be assumed to be nearly identical in subjects without endogenous insulin secretion, this is not the case in subjects with endogenous insulin secretion. Since it is not possible to obtain blood samples from the portal vein (in humans), two approaches are currently available: either the endogenous insulin secretion can be suppressed by infusion of somatostatin whereby the peripheral insulin concentration may be assumed to reflect the portal one, or the portal insulin concentrations may be calculated. By the use of somatostatin, not only the insulin secretion, but also the secretion of growth hormone and pancreatic glucagon is inhibited; and furthermore, the portal blood flow is diminished. Therefore in the current study we have used the last approach. Calculating portal insulin concentrations in the control subjects we assumed a fasting portal venous-systemic insulin gradient of 2.4. Although the exact value in our control subjects is not known, there is no doubt that the insulin concentration in the portal vein is $2-3$-fold higher than in peripheral arteries [11-20]. The value of 2.4 represents, the mean of values reported in the literature and therefore provides a reasonable estimate. In diabetic patients without endogenous insulin secretion the portal venoussystemic gradient has not been studied. In pancreatectomised dogs the gradient has been demonstrated to be less than one during peripheral insulin infusion [32]. It is therefore possible that by using a value of one we have overestimated portal insulin concentrations in the diabetic patients and that the dose-response curve should be even more left-ward shifted, thus magnifying the difference in hepatic insulin sensitivity.

Although the dose-response curve for hepatic glucose production versus portal insulin levels in Figure 3 is clearly left-ward shifted in diabetic patients compared to control subjects, it may be argued that the slope of the curves, i.e. $\Delta$ glucose production/ $\Delta$ insulin concentration is steeper in control subjects than in diabetic patients and therefore that the diabetic patients may be less sensitive than normal subjects. However, such an interpretation requires linearity of the dose-response effect or equality of insulin action in the insulin intervals compared. Neither of these requirements can be assumed to be fullfilled (different basal portal insulin values). From a clinical standpoint the demonstration of identical glucose production rates at lower portal insulin levels and lower glucose production rates at comparable portal insulin levels must indicate that insulin action is enhanced in the diabetic patients. Therefore it seems valid to conclude that although the peripheral tissues are insulin resistant in Type 1 diabetes the hepatic tissue is more sensitive than normal to the action of insulin.

Considering that conventionally treated Type 1 diabetic patients are characterised by peripheral hyperinsulinaemia [33-35], and that portal insulin levels are subnormal during the day, the results in the present study provide important information concerning the pathogenesis of the changes in insulin action. First of all, insulin resistance is not a universal feature of Type 1 diabetes. Secondly, the changes in insulin sensitivity in vivo appear to be inversely related to the changes in the diurnal insulin concentrations presented to the tissues. It has been noted previously that the insulin level under certain conditions may inversely regulate the insulin receptor number in vitro [36-40]. Furthermore, in a recent study, $40 \mathrm{~h}$ of modest hyperinsulinaemia was found to induce peripheral insulin resistance at the postreceptor level in normal subjects [41-42]. In animal studies hypoinsulinaemia has been found to be associated with increased insulin binding to liver cell membranes in vitro [43-44], and recently in the streptozotocin diabetic rat the hepatic insulin sensitivity in vivo was found to be increased [45]. Thus, based on these findings, the enhanced insulin sensitivity in the liver may be caused by portal hypoinsulinaemia, whereas the peripheral insulin resistance may be due to hyperinsulinaemia.

Clinically, the present demonstration of an in- 
creased hepatic insulin sensitivity may explain why many Type 1 diabetic patients, despite pronounced peripheral insulin resistance, can be treated with daily insulin doses that are lower than the amounts of endogenously secreted insulin in non-diabetic subjects. On the other hand, our attention is drawn towards the $a b$ normal peripheral insulin levels in Type 1 diabetes induced by the present mode of peripheral insulin treatment. This induced hyperinsulinaemia, together with hyperglycaemia are incriminated as risk factors in the pathogenesis of diabetic vascular complications.

In summary, the present study demonstrates that in Type 1 diabetic patients the insulin action is changed in two directions: in peripheral tissues insulin sensitivity is decreased and in hepatic tissue insulin sensitivity is increased. Presumably, these changes are acquired defects secondary to the absence of endogenous insulin secretion in combination with the present mode of peripheral insulin treatment.

Acknowledgements. The technical assistance of Ms. L.Blak, Ms. P. Sonne, Ms. T. Skrumsager and Ms. J. Søholt is gratefully acknowledged as is the secretarial assistance of Ms. E. Buntzen. This study has been supported by grants from the Danish Medical Research Council, the Danish Diabetes Association, Aarhus Universitets Forskningsfond, Nordisk Insulin Fond, Kong Chr. X's Fond, Klassisk Klinisk Forskning, University of Aarhus, Fonden til Lægevidenskabens fremme.

\section{References}

1. DeFronzo RA, Simonson D, Ferrannini E (1982) Hepatic and peripheral insulin resistance: a common feature of Type 2 (noninsulin-dependent) and Type 1 (insulin-dependent) diabetes mellitus. Diabetologia 23: 313-319

2. DeFronzo RA, Hendler R, Simonson D (1982) Insulin resistance is a prominent feature of insulin-dependent diabetes. Diabetes 31: 795-801

3. DelPrato $S$, Nosadini R, Tiengo A, Tessari $P$, Avogaro A, Trevisan R, Valerio A, Muggeo M, Cobelli C, Toffolo G (1983) Insulin-mediated glucose disposal in type 1 diabetes: evidence for insulin resistance. J Clin Endocrinol Metab 57: 904-910

4. Yki-Järvinen $H$, Koivisto VA (1984) Continuous subcutaneous insulin infusion therapy decreases insulin resistance in type 1 diabetes. J Clin Endocrinol Metab 58: 659-666

5. Yki-Järvinen H, Koivisto VA (1984) Insulin sensitivity in newly diagnosed type 1 diabetics after ketoacidosis and after three months of insulin therapy. $\mathbf{J}$ Clin Endocrinol Metab 59: 371-378

6. Lager I, Lönnroth P, Schenck H, Smith U (1983) Reversal of insulin resistance in type I diabetes after treatment with continuous subcutaneous insulin infusion. Br Med J 287: 1661-1664

7. Pernet A, Trimble ER, Kuntschen F, Damoiseaux P, Assal JP, Hahn C, Renold AE (1984) Insulin resistance in Type 1 (insulindependent) diabetes: dependence on plasma insulin concentration. Diabetologia 26: 255-260

8. Beck-Nielsen H, Richelsen B, Hasling C, Hother Nielsen O, Heding L, Sørensen NS (1984) Improved in vivo insulin effect during continuous subcutaneous insulin infusion in patients with IDDM. Diabetes 33: 832-837

9. Proietto J, Nankervis A, Aitken P, Caruso G, Alford F (1983) Glucose utilization in Type 1 (insulin-dependent) diabetes: evidence for a defect not reversible by acute elevations of insulin. Diabetologia 25: 331-335

10. Revers RR, Kolterman OG, Scarlett JA, Stuart Gray R, Olefs- ky JM (1984) Lack of in vivo insulin resistance in controlled insulin-dependent, type 1, diabetic patients. J Clin Endocrinol Metab 58: 353-358

11. Blackard WG, Nelson NC (1970) Portal and peripheral vein immunoreactive insulin concentrations before and after glucose infusion. Diabetes 19: 302-306

12. Greco AV, Crucitti F, Ghirlanda G, Manna R, Altomonte L, Rebuzzi AG, Bertoli A (1979) Insulin and glucagon concentrations in portal and peripheral veins in patients with hepatic cirrhosis. Diabetologia 17: 23-28

13. Felig P, Gusberg R, Hendler R, Gump F, Kinney J (1974) Concentrations of glucagon and the insulin: glucagon ratio in the portal and peripheral circulation. Proc Soc Exp Biol Med 147: $88-90$

14. Blackard W, Nelson N, Andrews S (1974) Portal and peripheral vein immunoreactive glucagon concentrations after arginine and glucose infusions. Diabetes 23: 199-202

15. Erwald R, Hed R, Nygren A, Rojdmark S, Wiechel K (1974) Comparison of the effect of intraportal and intravenous infusion of insulin on blood glucose and free fatty acids in peripheral venous blood of man. Acta Med Scand 195: 351-357

16. Horwitz D, Starr J, Mako M, Blackard W, Rubenstein A (1975) Proinsulin, insulin and C-peptide concentrations in human portal and peripheral blood. J Clin Invest 55: 1278-1283

17. Hed R, Nygren A, Rojdmark R, Sundblad L, Wiechel K (1979) Insulin in portal hepatic and peripheral venous blood after glucose, tolbutamide and glipizide stimulation. Acta Med Scand 205: 221-225

18. Erwald R, Hed R, Nygren A, Rojdmark S, Sundblad L, Wiechel K (1971) Immunoreactive insulin in the portal and the peripheral venous blood after intravenous tolbutamide administration. Diabetes 20:686-690

19. Pelkonen R, Kallio H, Suoranta H, Karonen S (1981) Plasma insulin, C-peptide and blood glucose in portal, hepatic and peripheral veins in liver cirrhosis. Effect of intravenous tolbutamide. Acta Endocrinol 97: 496-502

20. Berger W, Göschke H, Moppert J, Künzli H (1973) Insulin concentrations in portal venous and peripheral venous blood in man following administration of Glucose, Galactose, Xylitol and Tolbutamide. Horm Metab Res 5: 4-8

21. McGuire EAH, Helderman JH, Tobin JD, Andres R, Berman M (1976) Effects of arterial versus venous sampling on analysis of glucose kinetics in man. J Appl Physiol 41: 565-573

22. Heding LG (1966) A simplified insulin radioimmunoassay method. In: Donato L (ed) Labelled proteins in tracer studies. European atomic energy community, Brussels, pp 345-350

23. Heding LG (1975) Radioimmunological determination of human C-peptide in serum. Diabetologia 11: 541-548

24. Nakagawa S, Nakayama $H$, Sasaki T, Yoshino K, Yu YY, Shinozaki K, Aoki S, Mashimo K (1973) A simple method for the determination of serum free insulin levels in insulin treated patients. Diabetes 22: 590-600

25. Christiansen AH (1973) Radioimmunoelectrophoresis in the determination of insulin binding to IgG. Methodological studies. Horm Metab Res 5: 147-154

26. Johnson RN, Metcalf PA, Baker JR (1982) Fructosamine: a new approach to the estimation of serum glycosylprotein. An index of diabetic control. Clin Chim Acta 127: 87-95

27. Sherwin RS, Kramer KJ, Tobin JD, Insel PA, Liljenquist JE, Berman M, Andres R (1974) A model of the kinetics of insulin in man. J Clin Invest 53: 1481-1492

28. Steele R (1959) Influences of glucose loading and of injected insulin on hepatic glucose output. Ann NY Acad Sci 82: 420-430

29. Cowan JS, Hetenyi G (1971) Glucoregulatory responses in normal and diabetic dogs recorded by a new tracer method. Metabolism 20: $360-372$

30. De Feo P, Perriello G, De Cosmo S, Ventura MM, Campbell PJ, Brunetti P, Gerich JE, Bolli GB (1986) Comparison of glucose counterregulation during short-term and prolonged hypoglycemia in normal humans. Diabetes 35: 563-569

31. Simonson DC, Tamborlane WV, Sherwin RS, Smith JD, DeFron- 
zo RA (1985) Improved insulin sensitivity in patients with type 1 diabetes mellitus after CSII. Diabetes 34 [Suppl 3]: 80-86

32. Ishida T, Chap Z, Chou J, Lewis RM, Hartley CJ, Entman ML, Field JB (1984) Effects of portal and peripheral venous insulin infusion on glucose production and utilization in depancreatized, conscious dogs. Diabetes 33: 984-990

33. Rizza RA, Gerich JE, Haymond MW, Westland RE, Hall LD, Clemens AH, Service FJ (1980) Control of blood sugar in insulin-dependent diabetes: comparison of an artificial endocrine pancreas, continuous subcutaneous insulin infusion, and intensified conventional insulin therapy. N Engl J Med 303: 1313-1318

34. Bergenstal RM, Dupre J, Lawson PM, Rizza RA, Rubinstein AH (1985) Observations on C-peptide and free insulin in the blood during continous subcutaneous insulin infusion and conventional insulin therapy. Diabetes 34 [Suppl 3]: 31-36

35. Pedersen $\mathrm{O}$, Hjøllund $\mathrm{E}$, Lindskov $\mathrm{HO}$, Beck-Nielsen $\mathrm{H}$, Jensen J (1982) Circadian profiles of insulin receptors in insulin-dependent diabetics in usual and poor metabolic control. Am J Physiol 242: E127-E136

36. Gavin JR, Roth J, Neville DM, DeMeyts P, Buell DN (1974) Insulin-dependent regulation of insulin receptor concentrations: a direct demonstration in cell culture. Proc Natl Acad Sci USA 71: $84-88$

37. Olefsky JM, Reaven GM (1977) Insulin binding in diabetes: relationship with plasma insulin levels and insulin sensitivity. Diabetes 26: $680-688$

38. Olefsky JM (1981) Insulin resistance and insulin action: an in vitro and in vivo perspective. Diabetes 30: 148-162

39. Marshall S, Olefsky JM (1980) Effects of insulin incubation on insulin binding, glucose transport, and insulin degradation by isolated rat adipocytes: evidence for hormone induced desensiti- zation at the receptor and postreceptor level. J Clin Invest 66: $763-772$

40. Livingston JN, Purvis BJ, Lockwood DH (1978) Insulin-dependent regulation of the insulin sensitivity of adipocytes. Nature 273: $394-396$

41. Mandarino L, Baker B, Rizza RA, Genest J, Gerich J (1984) Infusion of insulin impairs human adipocyte glucose metabolism in vitro without decreasing adipocyte insulin receptor binding. Diabetologia 27: 358-363

42. Rizza RA, Mandarino LJ, Genest J, Baker BA, Gerich JE (1985) Production of insulin resistance by hyperinsulinaemia in man. Diabetologia 28: 70-75

43. Hepp KD, Langley J, von Funcke HJ, Renner R, Kemmler W (1975) Increased insulin binding capacity of liver membranes from diabetic chinese hamsters. Nature 258: 154

44. Davidson MB, Kaplan SA (1977) Increased insulin binding by hepatic plasma membranes from diabetic rats. J Clin Invest 59: $22-30$

45. Kergoat M, Portha B (1985) In vivo hepatic and peripheral insulin sensitivity in rats with non-insulin-dependent diabetes induced by streptozocin. Diabetes 34: 1120-1126

Received: 3 December 1986

and in revised form: 27 August 1987

Dr. Ole Hother-Nielsen

Hvidøre Hospital

Emiliekildevej 1

DK-2930 Klampenborg

Denmark 